\title{
Probiotic salami with fat and curing salts reduction: physicochemical, textural and sensory characteristics
}

\author{
Mariana Nougalli ROSELINO ${ }^{1 *}$, Jéssica Ferraz de ALMEIDA $^{1}$, Izabela Correia COZENTINO ${ }^{1}$, \\ Josiane Marcia Maria CANAAN ${ }^{1}$, Roseli Aparecida PINTO${ }^{1}$, Graciela Font de VALDEZ ${ }^{2}$, Elizeu Antonio ROSSI ${ }^{1}$, \\ Daniela Cardoso Umbelino CAVALLINI ${ }^{1}$
}

\begin{abstract}
This work was evaluated the physicochemical, textural and the sensory properties of meat products fermented with traditional or probiotic cultures with lower fat and curing salt content. Chemical composition was evaluated in T30 and instrumental texture was determined during the experimental protocol. A sensory profile evaluation was carried out using the quantitative descriptive analysis (QDA) and the acceptance test. The lowest fat content was found in the salamis processed with reduced pork fat. Texture profile analysis the F5 exhibited the lowest mean value of hardness. In QDA, the results showed that the F1 exhibited the highest mean value of regularity of the border, brightness, softness and smoked, due to the greater amount of fat in their composition. The results revealed that, in T30, there was good acceptance for all formulations and during the storage period, the mean values remained high. The consumers demonstrated a positive purchase intention for all formulations.
\end{abstract}

Keywords: probiotic salami; chemical composition; texture profile; sensory properties.

Practical Application: Potentially probiotic fermented meat product using cultures with hypolipidemic properties.

\section{Introduction}

Currently, consumers are searching for safe and nutritious products, besides being innovative and attractive, as functional foods are. In this sense, meat products have been criticized by their large amount of animal fat, nitrite and nitrate. Thus, the search for new products to be developed has aroused great interest, so as to meet the consumer's needs and obtain products that are healthier from a nutritional point of view (Rubio et al., 2014a).

The total or partial replacement of traditional starter cultures for probiotic ones can contribute to the safety of the final product and offer sensory advantages, as well as technological, nutritional and health benefits, representing an attractive alternative for the food industry (Pidcock et al., 2002; Muthukumarasamy \& Holley, 2007; Rubio et al., 2014b)

In the meat industry, the use of probiotics proved to be most promising for fermented products, such as salami, which are usually processed and consumed without heating (Työppönen et al., 2003; Ammor \& Mayo, 2007; Sidira et al., 2016).

Moreover, the use of olive oil as a partial replacement for animal fat has shown to be effective in getting obtaining meat products with low fat content (Severini et al., 2003; Bolumar et al., 2015), which would promote a repositioning of the product on the market.
The probiotic cultures E.faecium CRL 183 and L.acidophilus CRL 1014 have been extensively studied for its health benefits. Previous results demonstrated their ability to remove cholesterol in vitro (Rossi et al., 1994). The E. faecium CRL 183 strain was able to modulate the intestinal microbiota (Bedani, 2008; Cavallini et al., 2011) and the lipid profile (Cavallini et al., 2016) reduce the risk of colon (Sivieri et al., 2008) and breast cancer developing (Kinouchi, 2006) and alleviate the symptoms of ulcerative colitis (Celiberto et al., 2015). To the present time, such strains and their beneficial properties were evaluated only in soy-based products.

Therefore, this study was aimed producing a potential probiotic fermented salami with fat and curing salts reduction. Effects on sensory properties were studied, as well as the influence on texture and chemical composition.

\section{Materials and methods}

\subsection{Development of fermented salami}

The fermented salamis were produced in seven different formulations, according to the Italian salami manufacturing procedures proposed by Severini et al. (2003), Koutsopoulos et al. (2008), Macedo et al. (2008) with a few modifications. All formulations were processed in three batches on different days.

${ }^{1}$ Departamento de Alimentos e Nutrição, Faculdade de Ciências Farmacêuticas, Universidade Estadual Paulista - UNESP, Araraquara, SP, Brasil

${ }^{2}$ Centro de Referencia para Lactobacilos - CERELA, San Miguel de Tucumán, Tucumán, Argentina

${ }^{\star}$ Corresponding author: mari_roselino@yahoo.com.br 
Formulation F1 (control formulation) was produced without fat and curing salts content reduction $(0.015 \%$ nitrite and $0.005 \%$ nitrate), and with traditional cultures (Pediococcus pentosaceus/Staphylococcus xylosus).

The other six formulations (F2 to F7) were produced with $8 \%$ pork fat, representing a replacement of approximately $60 \%$ in pork fat used in traditional formulations (T1: $20 \mathrm{~g} / 100 \mathrm{~g}$ ) (Terra, 1998). Extra virgin olive oil, pre-emulsified with sodium caseinate $(2 \mathrm{~g} / 100 \mathrm{~g})$, was used to preserve the sensory characteristics of the salami. The formulation 2 (F2) with traditional cultures and without curing salt reduction. The formulation 3 (F3) with traditional cultures and with curing salt reduction $(0.007 \%$ nitrite and $0.003 \%$ nitrate). The formulations 4 and 5 (F4 and F5) with probiotic culture (E. faecium CRL183) and without and with curing salt reduction, respectively. The formulations 6 and 7 (F6 and F7) with probiotic culture (L. acidophilus CRL1014) and without and with curing salt reduction, respectively.

The remaining ingredients were added in the following amounts: $61.5 \%$ pork meat, $28.5 \%$ cow meat, $8.0 \%$ pork fat, $2.0 \%$ olive oil, $2.5 \%$ sodium chloride, $0.5 \%$, sodium ascorbate, $0.5 \%$ sucrose, $0.7 \%$ lactose, $0.05 \%$ garlic powder, and $0.13 \%$ white pepper. The starter cultures (probiotic and traditional ones) were added in a sufficient amount to reach at least $8 \log \mathrm{CFU} / \mathrm{g}$. Probiotic cultures were propagated in M17 broth (Himedia, India) for 24 hours at $37^{\circ} \mathrm{C}$ (E. faecium CRL183) or an MRS medium (Man Rogosa Sharpe, Accumedia, USA) for $72 \mathrm{~h}$ at $37^{\circ} \mathrm{C}$ (L. acidophilus CRL1014), and the cells were precipitated by centrifugation $\left(1173 \mathrm{xg} / 15 \mathrm{~min}, 4^{\circ} \mathrm{C}\right)$ and washed with phosphate water.

The salamis were maintained in a chamber for 7 (fermentation - temperature: $25-18^{\circ} \mathrm{C}$ ) and for 23 days (ripening- temperature: $15{ }^{\circ} \mathrm{C}$ ), with controlled temperature and humidity, totaling 30 days (Koutsopoulos et al., 2008; Macedo et al., 2008). After this period, the salamis were vacuum-packed and stored under refrigeration for 90 days.

\subsection{Chemical composition}

Moisture, ash, protein and fat contents were determined according to the Association of official analytical chemists (Association of Official Analytical Chemists, 2005). The determination of total carbohydrates was performed by difference (Fuchs et al., 2005). The total calorie value (TCV) content of the products was calculated based on the content of proteins, carbohydrates and lipids, follow de equation bellow: TCV $(\mathrm{kcal})=[$ proteins $(\mathrm{g}) \times 4)]+[$ carbohydrates $(\mathrm{g}) \times 4]+[$ fat $(\mathrm{g}) \times 9]$.

\subsection{Instrumental measurement of texture}

The texture profile was determined using a Universal TA-XTplus Texture Analyzer (Stable micro systems, United Kingdom), by a test known as TPA (Texture Profile Analysis) (Bourne, 1978). The parameters determined hardness (g), elasticity, cohesiveness ( $\mathrm{g} \times \mathrm{mm})$, gumminess $(\mathrm{g})$ and chewiness (g x mm) (Liaros et al., 2009).

\subsection{Sensory analysis}

Sensory analyzes were carried out in a climatized $\left(22^{\circ} \mathrm{C}\right)$ individual cabins, and evaluated under white light, thereby ensuring comfort and privacy for the assessors. The sessions were held in the Laboratory of Sensory Analysis (Department of Food and Nutrition, UNESP). Water was provided for palate cleansing.

This research project was submitted and approved by the Research Ethics Committee from the Faculty of Pharmaceutical Sciences, under number CAAE 0657.4912.2.0000.5426. A Consent Term containing information about the research was prepared and presented to the assessors.

\subsection{Quantitative descriptive analysis}

The sensory profile evaluation of all seven salami samples was conducted by the quantitative descriptive analysis (QDA) according to the methodology proposed by Stone et al. (2012). This technique has been adopted to analyze various food products, and its principles and measures are well established (Gonzalez et al., 2011; Volpini-Rapina et al., 2012).

\subsection{Pre-selection of assessors}

Participants were recruited among FCFAr/UNESP undergraduates, graduates and employees, who presented themselves as salami consumers and expressed interest in becoming members of the sensory group to be trained. In the pre-selection, 30 candidates were submitted to sequential analysis proposed by Wald, using triangle tests (Amerine et al., 1965; Meilgaard et al., 1999), being approved only 22 candidates. The parameters used in the sequential analysis were: $P=0.45$ (maximum unacceptable ability), $P 1=0.70$ (minimum acceptable ability), $\alpha=0.05$ (likelihood of accepting a candidate without sensory acuity) and $\beta=0.05$ (likelihood of rejecting a candidate with sensory acuity). Based on these parameters, the sensory panelists were selected according to the number of triangular tests and the cumulative number of judgments. In this stage, two samples of commercial Italian salamis (Aurora and Sadia, Brazil) were used and the volunteers were asked to evaluate only the aroma and flavor of the products.

\subsection{Descriptive terminology development}

For the development of descriptive terminology, Repertory Grid technique according to Kelly's Method (Moskowitz, 1983) was used. All samples were presented in pairs, and the assessors described the similarities and differences between them. The 22 pre-selected volunteers evaluated the descriptive terms of the salamis and, by consensus, decided that 16 attributes would be sufficient to characterize the products. The descriptive terms were defined and the references for the maximum and minimum intensity of each attribute of the scale were provided by the pre-selected candidates (Table 1).

Training sessions to develop sensory memory and equalization among assessors team were held by direct contact of the individuals with maximum and minimum intensity references used for each attribute (Cadena \& Bolini, 2011). The sessions were conducted in four days, with two to three daily sessions. 
Table 1. Descriptors used for sensory profiling of Italian style salami.

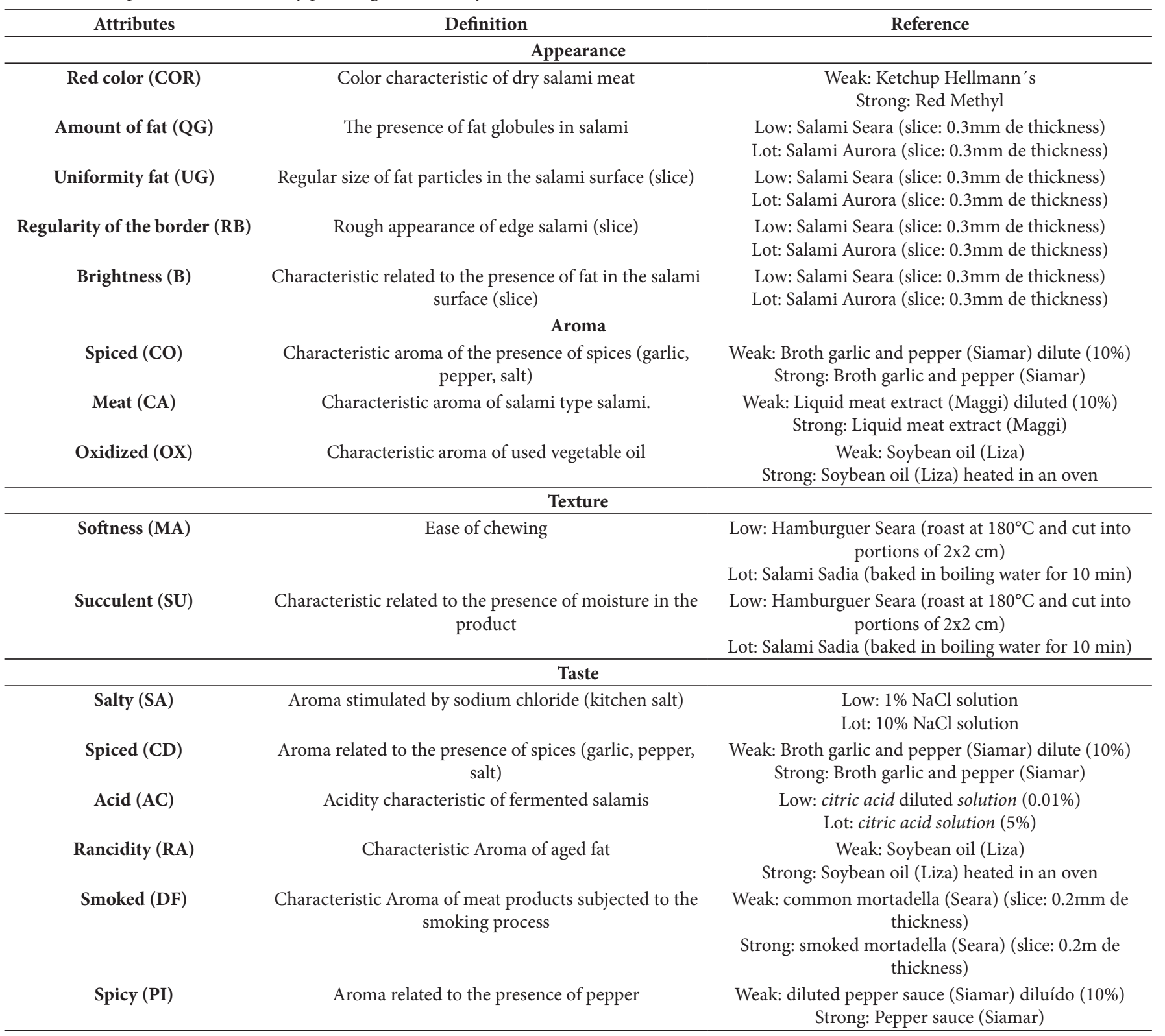

\subsection{Selection of subjects for the QDA}

The selection of the final team was based on their power of discrimination between samples $(\mathrm{p}<0.30)$, repeatability $(\mathrm{p}>0.05)$ and consensus between the assessors (Damásio \& Costell, 1991). The samples were evaluated in monadic sequence with three replicates, following a balanced complete block design (Wakeling \& MacFie, 1995).

\section{Evaluation by the quantitative descriptive analysis (QDA)}

The selected assessors evaluated the seven salami samples according to the previously determined references for all attributes. They received portions of $15 \mathrm{~g}$ of salami sample and were asked to rate the intensity of each attribute using a continuous 9-cm unstructured line scale with anchors "weak" or "none" on the left and "strong" on the right. The samples were submitted to analysis and coded with three-digit random numbers in monadic sequence and four replications (Macfie et al., 1989).

\subsection{Acceptance test}

An acceptance testing evaluated the samples' appearance, color, aroma, texture, flavor and overall impression using a structured 9-points hedonic scale (Stone \& Sidel, 1993). Samples were presented in a randomized complete block, coded with three-digit numbers in monadic sequence. The team consisted of 60 untrained volunteers which were regular consumers of salami. 


\subsection{Statistical analysis}

QDA results were analyzed by ANOVA using two factors (assessors and sample) and their interaction, followed by a Tukey's test ( $p>0.05)$. Principal Component Analysis (PCA) was also conducted to analyze the QDA results. These analyses were carried out using the Statistical Analysis System SAS 9.1.2. The acceptability results were analyzed by the ANOVA and Tukey's test $(\mathrm{p}<0.05)$ using the BioEstat 5.0.

\section{Results and discussion}

\subsection{Centesimal composition}

With respect to the chemical composition of the samples (Table 2), the results at the end of the ripening period salamis ready for consumption - are in accordance with Annex V of Normative Instruction \# 22 of the Ministry of Agriculture and Supply of July 31 (2000), which recommends the following contents: moisture (max.) $40.0 \%$, fat (max.) $35.0 \%$, protein (min.) $20.0 \%$ and total carbohydrates (max.) $4.0 \%$ (Brasil, 2000).

Del Nobile et al. (2009) analyzed the effect of fat substitution by extra virgin olive oil on the chemical composition of an Italian-type salami and found the following mean values for the different formulations: moisture content between $27.50 \%$ and $37.40 \%$, fat content between $23.6 \%$ and $29.84 \%$, proteins ranging from $30.88 \%$ to $38.48 \%$, and ash content between 5.73 and $6.85 \%$. These results are consistent with the values found in this study, i.e. the products ready for consumption.

It was also found, as expected, a lower total fat content in fermented salamis processed with $60 \%$ pork fat reduction. In these formulations, the pork fat was replaced by extra virgin olive oil, which had been pre-emulsified with sodium caseinate (2\%), to preserve the sensory characteristics and improve the fatty acid profile of the products. Consequently, the caloric content of the reduced fat formulations (T2 to T7) was lower $(\mathrm{p}<0.05)$. It was also observed an increase in ash content, proteins and lipids as a function of storage time $(\mathrm{p}<0.05)$, as a result of moisture reduction in the salamis.

\subsection{Instrumental texture}

Table 3 shows the results of the Texture Profile Analysis.

The parameters hardness and gumminess exhibited an increase over the course of the analysis times, while chewiness increased at the end of the ripening period (T30) in all formulations. The elasticity of the salamis was reduced in the same period, and their cohesiveness remained largely unchanged until T90.

Only in the last period, T120, it was not possible to determine the texture profile of the formulations with fat reduction, indicating that hardness was above (exceeded) the maximum power that the machine can apply to the sample (operate). This result suggests that the partial replacement of animal fat for extra virgin olive oil results in increased hardness, which is a fact that may compromise the sensory quality of the product, especially during the storage period.

It was observed that in T90, between the formulations with reduced fat content, F5 presented the lowest mean value of hardness $(\mathrm{p}<0.05)$, indicating that this formulation exhibited the higher texture quality.

Andrés et al. (2006) evaluated the effect of different levels of fat on the quality of chicken salamis, and concluded that there was increased hardness with storage $\left(4^{\circ} \mathrm{C}\right)$. Similar results were reported by Candogan \& Kolsarici (2003) for salamis with fat reduction and Kunrath \& Savoldi (2014) that evaluated the application of propolis in Italian salami. This increase in hardness is probably due to the water loss of the product after being cooled.

Gumminess and chewiness are dependent on the hardness variable, which would explain an increase in these parameters due to the salamis' increased hardness. As the salami becomes harder as storage time passes, there is a reduction of its elasticity.

\subsection{Quantitative Descriptive Analysis (QDA)}

Volunteers who had the power of discrimination $(\mathrm{p}<0.30)$, repeatability $(p>0.05)$ and agreement with the other team members were selected. The nine selected assessors conducted the final analysis, once again in triplicate. The results of QDA are represented graphically by the spider and PCA graphs (Figure 1).

Table 2. Mean ( \pm standard deviations) for centesimal composition (g/100g) at the end of the ripening period - salamis ready for consumption.

\begin{tabular}{ccccccc}
\hline Formulation & Ash & Protein & Fat & Moisture & Carbohydrates & Calories \\
\hline F1 & $3.27^{\mathrm{c}} \pm 0.14$ & $28.77^{\mathrm{c}} \pm 1.96$ & $31.34^{\mathrm{a}} \pm 2.85$ & $33.16^{\mathrm{ab}} \pm 1.23$ & $3.46^{\mathrm{a}} \pm 0.27$ & $410.99^{\mathrm{a}} \pm 11.55$ \\
F2 & $6.00^{\mathrm{b}} \pm 0.28$ & $31.19^{\mathrm{bc}} \pm 2.51$ & $24.47^{\mathrm{b}} \pm 0.81$ & $34.61^{\mathrm{a}} \pm 2.32$ & $3.73^{\mathrm{a}} \pm 0.41$ & $357.65^{\mathrm{b}} \pm 12.91$ \\
F3 & $6.50^{\mathrm{ab}} \pm 0.29$ & $36.11^{\mathrm{a}} \pm 0.37$ & $21.86^{\mathrm{c}} \pm 0.55$ & $31.62^{\mathrm{b}} \pm 1.03$ & $3.91^{\mathrm{a}} \pm 0.28$ & $356.84^{\mathrm{b}} \pm 5.10$ \\
F4 & $6.17^{\mathrm{b}} \pm 0.03$ & $35.53^{\mathrm{a}} \pm 1.10$ & $20.80^{\mathrm{c}} \pm 1.10$ & $33.84^{\mathrm{ab}} \pm 2.14$ & $3.66^{\mathrm{a}} \pm 0.33$ & $366.51^{\mathrm{ab}} \pm 54.97$ \\
F5 & $6.96^{\mathrm{ab}} \pm 0.96$ & $32.08^{\mathrm{bc}} \pm 3.59$ & $23.00^{\mathrm{bc}} \pm 1.11$ & $33.91^{\mathrm{ab}} \pm 1.61$ & $4.05^{\mathrm{a}} \pm 1.66$ & $349.79^{\mathrm{b}} \pm 10.31$ \\
F6 & $7.49^{\mathrm{a}} \pm 1.04$ & $34.42^{\mathrm{ab}} \pm 0.46$ & $22.36^{\mathrm{bc}} \pm 1.09$ & $31.90^{\mathrm{ab}} \pm 1.23$ & $3.94^{\mathrm{a}} \pm 0.34$ & $354.23^{\mathrm{b}} \pm 8.03$ \\
F7 & $6.38^{\mathrm{b}} \pm 0.22$ & $33.65^{\mathrm{ab}} \pm 0.70$ & $22.93^{\mathrm{bc}} \pm 0.93$ & $33.16^{\mathrm{ab}} \pm 0.50$ & $3.89^{\mathrm{a}} \pm 0.29$ & $356.53^{\mathrm{b}} \pm 4.84$ \\
\hline
\end{tabular}

F1 - traditional cultures without fat and curing salts reduction (nitrite and nitrate $0.015 \% 0.005 \%$ ); F2 - traditional cultures without curing salts reduction; F3 - traditional cultures with curing salts reduction (nitrite and nitrate $0.007 \% 0.003 \%$ ); F4 and F5 - probiotic culture (E. faecium CRL183) without and with curing salts reduction, respectively; F6 and F7 - probiotic culture (L. acidophilus CRL1014) without and with curing salts reduction, respectively. Analysis of formulations: means with the same lowercase letters in the same column do not differ by Tukey test $(\mathrm{P}<0.05)$. 
Table 3. Mean ( \pm standard deviations) obtained in the test TPA (Texture Profile Analysis), for hardness, cohesiveness, elasticity, gumminess and chewiness to the different formulations and processing steps.

\begin{tabular}{|c|c|c|c|c|c|c|c|}
\hline \multirow{2}{*}{ Time/ Attributes } & \multicolumn{7}{|c|}{ Formulations } \\
\hline & F1 & F2 & F3 & F4 & F5 & F6 & F7 \\
\hline \multicolumn{8}{|l|}{ T0 } \\
\hline Hardness & $1.67^{\mathrm{bE}} \pm 0.18$ & $1.78^{\mathrm{abD}} \pm 0.09$ & $2.12^{\mathrm{aD}} \pm 0.06$ & $1.93^{\mathrm{abD}} \pm 0.20$ & $2.08^{\mathrm{abD}} \pm 0.33$ & $1.90^{\mathrm{abD}} \pm 0.12$ & $2.00^{\mathrm{aD}} \pm 0.16$ \\
\hline Cohesiveness & $0.53^{\mathrm{abBC}} \pm 0.04$ & $0.57^{\mathrm{aA}} \pm 0.04$ & $0.48^{\mathrm{bB}} \pm 0.03$ & $0.51^{\mathrm{abA}} \pm 0.05$ & $0.54^{\mathrm{abB}} \pm 0.03$ & $0.56^{\mathrm{aA}} \pm 0.03$ & $0.51^{\mathrm{cbB}} \pm 0.03$ \\
\hline Elasticity & $1.99^{\mathrm{aA}} \pm 0.41$ & $1.75^{\mathrm{abA}} \pm 0.14$ & $1.45^{\mathrm{bA}} \pm 0.14$ & $1.44^{\mathrm{bA}} \pm 0.12$ & $1.36^{\mathrm{bA}} \pm 0.25$ & $1.67^{\mathrm{abA}} \pm 0.23$ & $1.56^{\mathrm{bA}} \pm 0.09$ \\
\hline Gumminess & $0.89^{\mathrm{bF}} \pm 0.16$ & $0.99^{\mathrm{abD}} \pm 0.10$ & $1.03^{\mathrm{abE}} \pm 0.05$ & $0.99^{\mathrm{bD}} \pm 0.17$ & $1.15^{\mathrm{aE}} \pm 0.16$ & $1.01^{\mathrm{abE}} \pm 0.06$ & $1.04^{\mathrm{abE}} \pm 0.04$ \\
\hline Hardness & $9.44^{\mathrm{bD}} \pm 1.74$ & $13.86^{\mathrm{aC}} \pm 1.83$ & $13.42^{\mathrm{aC}} \pm 0.79$ & $11.57^{\mathrm{abC}} \pm 1.58$ & $11.25^{\mathrm{abC}} \pm 2.17$ & $12.71^{\mathrm{aC}} \pm 0.19$ & $12.79^{\mathrm{aC}} \pm 1.04$ \\
\hline Cohesiveness & $0.61^{\mathrm{bA}} \pm 0.05$ & $0.50^{\mathrm{cdA}} \pm 0.05$ & $0.54^{\mathrm{bcA}} \pm 0.02$ & $0.43^{\mathrm{dB}} \pm 0.02$ & $0.83^{\mathrm{aA}} \pm 0.08$ & $0.49^{\mathrm{cdB}} \pm 0.03$ & $0.46^{\mathrm{cdC}} \pm 0.02$ \\
\hline Elasticity & $1.23^{\mathrm{bB}} \pm 0.07$ & $1.32^{\mathrm{bB}} \pm 0.12$ & $1.32^{\mathrm{bA}} \pm 0.18$ & $1.26^{\mathrm{bB}} \pm 0.03$ & $1.17^{\mathrm{bB}} \pm 0.06$ & $1.29^{\mathrm{bB}} \pm 0.05$ & $1.56^{\mathrm{aA}} \pm 0.13$ \\
\hline Gumminess & $3.61^{\mathrm{dE}} \pm 0.25$ & $5.83^{\mathrm{cD}} \pm 0.52$ & $6.54^{\mathrm{bcD}} \pm 0.49$ & $6.78^{\mathrm{bcC}} \pm 1.20$ & $8.70^{\mathrm{aD}} \pm 1.07$ & $7.28^{\mathrm{bD}} \pm 0.14$ & $6.51^{\mathrm{bcD}} \pm 0.27$ \\
\hline Chewiness & $2.62^{\mathrm{dE}} \pm 0.16$ & $3.71^{\mathrm{abC}} \pm 0.08$ & $3.92^{\mathrm{aD}} \pm 0.37$ & $3.46^{\mathrm{bcC}} \pm 0.14$ & $3.44^{\mathrm{bcC}} \pm 0.40$ & $3.16^{\mathrm{cC}} \pm 0.16$ & $3.10^{\mathrm{CC}} \pm 0.05$ \\
\hline Elasticity & $1.09^{\mathrm{aBC}} \pm 0.04$ & $0.96^{\mathrm{bB}} \pm 0.01$ & $0.82^{\mathrm{dB}} \pm 0.02$ & $0.84^{\mathrm{cdC}} \pm 0.02$ & $0.96^{\mathrm{bC}} \pm 0.01$ & $0.87^{\mathrm{cC}} \pm 0.02$ & $0.85^{\mathrm{cdB}} \pm 0.01$ \\
\hline Gumminess & $13.20^{\mathrm{bD}} \pm 1.72$ & $23.95^{\mathrm{aB}} \pm 3.55$ & $29.05^{\mathrm{aB}} \pm 1.86$ & $27.86^{\mathrm{aB}} \pm 0.64$ & $26.34^{\mathrm{aC}} \pm 4.73$ & $24.89^{\mathrm{aC}} \pm 3.57$ & $25.92^{\mathrm{aC}} \pm 3.44$ \\
\hline Chewiness & $5.15^{\mathrm{cD}} \pm 0.03$ & $24.25^{\mathrm{abA}} \pm 1.30$ & $23.62^{\mathrm{bA}} \pm 1.70$ & $25.80^{\mathrm{aA}} \pm 1.83$ & $23.46^{\mathrm{bA}} \pm 0.52$ & $23.37^{\mathrm{bA}} \pm 0.53$ & $24.11^{\mathrm{abA}} \pm 0.68$ \\
\hline \multicolumn{8}{|l|}{ T60 } \\
\hline Hardness & $49.06^{\mathrm{bB}} \pm 1.48$ & $46.64^{\mathrm{bB}} \pm 3.53$ & $46.05^{\mathrm{bB}} \pm 3.31$ & $59.54^{\mathrm{aAB}} \pm 0.14$ & $56.24^{\mathrm{aA}} \pm 2.32$ & $57.43^{\mathrm{aA}} \pm 0.84$ & $59.60^{\mathrm{aA}} \pm 0.02$ \\
\hline Cohesiveness & $0.50^{\mathrm{bcC}} \pm 0.02$ & $0.39^{\mathrm{dB}} \pm 0.07$ & $0.45^{\mathrm{cdB}} \pm 0.02$ & $0.54^{\mathrm{abA}} \pm 0.03$ & $0.56^{\mathrm{aB}} \pm 0.02$ & $0.57^{\mathrm{aA}} \pm 0.01$ & $0.56^{\mathrm{aA}} \pm 0.03$ \\
\hline Elasticity & $0.85^{\mathrm{aC}} \pm 0.01$ & $0.67^{\mathrm{bD}} \pm 0.15$ & $0.84^{\mathrm{aB}} \pm 0.02$ & $0.84^{\mathrm{aC}} \pm 0.01$ & $0.84^{\mathrm{aC}} \pm 0.01$ & $0.84^{\mathrm{aC}} \pm 0.03$ & $0.84^{\mathrm{aB}} \pm 0.01$ \\
\hline Gumminess & $24.59^{\mathrm{CC}} \pm 1.01$ & $18.41^{\mathrm{dC}} \pm 3.47$ & $22.44^{\mathrm{cdC}} \pm 1.94$ & $30.71^{\mathrm{bB}} \pm 3.67$ & $31.17^{\mathrm{bB}} \pm 2.33$ & $37.60^{\mathrm{aB}} \pm 0.39$ & $34.19^{\mathrm{abB}} \pm 0.22$ \\
\hline Chewiness & $11.14^{\mathrm{aC}} \pm 0.34$ & $12.01^{\mathrm{bcB}} \pm 1.37$ & $14.47^{\mathrm{aB}} \pm 1.49$ & $11.56^{\mathrm{cB}} \pm 0.29$ & $11.63^{\mathrm{cB}} \pm 1.02$ & $12.66^{\mathrm{abcB}} \pm 1.42$ & $13.62^{\mathrm{abB}} \pm 0.88$ \\
\hline \multicolumn{8}{|l|}{$\mathrm{T} 90$} \\
\hline Hardness & $50.79^{\mathrm{aB}} \pm 0.67$ & $60.14^{\mathrm{abA}} \pm 0.56$ & $61.33^{\mathrm{abA}} \pm 0.98$ & $60.49^{\mathrm{abA}} \pm 0.63$ & $55.44^{\mathrm{cA}} \pm 3.27$ & $62.72^{\mathrm{aA}} \pm 1.09$ & $59.41^{\mathrm{bA}} \pm 0.28$ \\
\hline Elasticity & $0.95^{\mathrm{BC}} \pm 0.01$ & $\mathrm{Nd}$ & $\mathrm{Nd}$ & $\mathrm{Nd}$ & $\mathrm{Nd}$ & $\mathrm{Nd}$ & $\mathrm{Nd}$ \\
\hline Gumminess & $48.44^{\mathrm{A}} \pm 1.84$ & $\mathrm{Nd}$ & $\mathrm{Nd}$ & $\mathrm{Nd}$ & $\mathrm{Nd}$ & $\mathrm{Nd}$ & $\mathrm{Nd}$ \\
\hline Chewiness & $13.76^{\mathrm{A}} \pm 0.29$ & $\mathrm{Nd}$ & $\mathrm{Nd}$ & $\mathrm{Nd}$ & $\mathrm{Nd}$ & $\mathrm{Nd}$ & $\mathrm{Nd}$ \\
\hline
\end{tabular}

F1 - traditional cultures without fat and curing salts reduction (nitrite and nitrate $0.015 \% 0.005 \%$ ); F2 - traditional cultures without curing salts reduction; F3 - traditional cultures with curing salts reduction (nitrite and nitrate $0.007 \% 0.003 \%$ ); F4 and F5 - probiotic culture (E. faecium CRL183) without and with curing salts reduction, respectively; F6 and F7 - probiotic culture (L. acidophilus CRL1014) without and with curing salts reduction, respectively. $\mathrm{T} 0=$ initial time; $\mathrm{T} 7=$ end of fermentation period; $\mathrm{T} 30=$ end of the ripening period; $\mathrm{T} 60$, $\mathrm{T} 90$ and $\mathrm{T} 120=$ storage time at $4{ }^{\circ} \mathrm{C} . \mathrm{Nd}=$ not determined. Analysis of formulations: means with the same lowercase letters in the same line, in the same time interval, do not differ by Tukey test $(\mathrm{P}<0.05)$. Analysis of time: means with capital letters for the same formulation at different times, do not differ by Tukey test $(\mathrm{p}<0.05)$.

The spider graph (Figure 1) suggests that control formulation (F1), without fat and curing salt reduction, presented a different behavior with higher mean values of brightness, edge regularity, softness and rancidity flavor. The other formulations showed a similar behavior, since the differences between mean values, even though being significant $(\mathrm{p}<0.05$ - Table 4$)$, were numerically lower.

The PCA chart (Figure 2) shows that $54.98 \%$ of the variation between the samples was explained by the first axis (PC1) and $14.85 \%$ by the second axis (PC2). The PCA clearly separated the formulations with fat reduction, control sample (F1), but it did not manage to separate them according to the starter culture used and the amount of curing salts. Attributes CO, MA, PI, CA, SA and COR contributed with greater weight to the variability associated with the second axis. While the other attributes were those that most contributed to the variability associated with the first axis. The control formulation (F1: without fat and curing salt content reduction and produced with traditional cultures) showed, once more, a different behavior from the others, being characterized by the attributes $\mathrm{B}, \mathrm{RA}, \mathrm{SU}, \mathrm{CD}, \mathrm{DF}$ and $\mathrm{RB}$ (PC1). The other formulations were located in closer regions, exhibiting the following characteristics: F2, F3 and F7 were located next to vectors $\mathrm{OX}, \mathrm{QG}$ and $\mathrm{UG}$; F4 close to vectors $\mathrm{CA}, \mathrm{RA}$ and COR; 


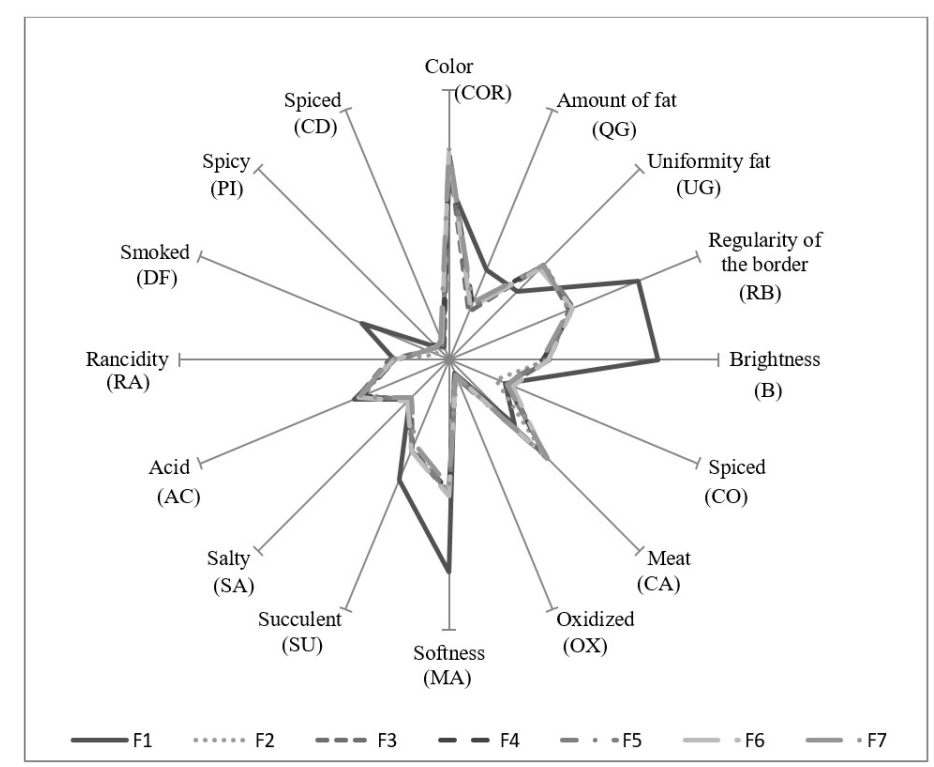

Figure 1. Spider graph with the average of the attributes of salami samples. F1 - traditional cultures without curing fat and curing salts reduction (nitrite and nitrate $0.015 \% 0.005 \%$ ); F2 - traditional cultures without curing salts reduction; F3 - traditional cultures with curing salts reduction (nitrite and nitrate $0.007 \% 0.003 \%$ ); F4 and F5 - probiotic culture (E. faecium CRL183) without and with curing salts reduction, respectively; F6 and F7 - probiotic culture (L. acidophilus CRL1014) without and with curing salts reduction, respectively.

Table 4. Results of QDA (mean \pm SD) of the different formulations of salamis.

\begin{tabular}{|c|c|c|c|c|c|c|c|c|}
\hline & Attributes & F1 & F2 & F3 & F4 & F5 & F6 & F7 \\
\hline \multirow[t]{5}{*}{ Appearance } & Color & $4.61^{b} \pm 0.21$ & $5.37^{\mathrm{a}} \pm 0.24$ & $5.32^{\mathrm{a}} \pm 0.17$ & $5.37^{\mathrm{a}} \pm 0.26$ & $5.44^{\mathrm{a}} \pm 0.25$ & $5.40^{\mathrm{a}} \pm 0.26$ & $5.46^{\mathrm{a}} \pm 0.32$ \\
\hline & Amount of fat & $2.52^{\mathrm{a}} \pm 0.26$ & $1.47^{b c} \pm 0.23$ & $1.33^{\mathrm{c}} \pm 0.18$ & $1.57^{\mathrm{b}} \pm 0.20$ & $1.51^{\mathrm{bc}} \pm 0.28$ & $1.46^{\mathrm{bc}} \pm 0.26$ & $1.60^{\mathrm{b}} \pm 0.23$ \\
\hline & Uniformity fat & $2.50^{\mathrm{b}} \pm 0.26$ & $3.50^{\mathrm{a}} \pm 0.24$ & $3.47^{\mathrm{a}} \pm 0.26$ & $3.44^{\mathrm{a}} \pm 0.28$ & $3.48^{\mathrm{a}} \pm 0.29$ & $3.33^{\mathrm{a}} \pm 0.21$ & $3.47^{\mathrm{a}} \pm 0.24$ \\
\hline & Regularity of the border & $5.32^{\mathrm{a}} \pm 0.25$ & $3.39^{\mathrm{b}} \pm 0.24$ & $3.38^{\mathrm{b}} \pm 0.22$ & $3.50^{\mathrm{b}} \pm 0.20$ & $3.50^{\mathrm{b}} \pm 0.19$ & $3.47^{\mathrm{b}} \pm 0.25$ & $3.37^{b} \pm 0.30$ \\
\hline & Brightness & $5.41^{\mathrm{a}} \pm 0.23$ & $2.58^{\mathrm{b}} \pm 0.28$ & $2.60^{\mathrm{b}} \pm 0.18$ & $2.44^{\mathrm{b}} \pm 0.29$ & $2.48^{\mathrm{b}} \pm 0.28$ & $2.57^{\mathrm{b}} \pm 0.28$ & $2.41^{b} \pm 0.23$ \\
\hline \multirow[t]{3}{*}{ Aroma } & Spiced & $1.58^{\mathrm{a}} \pm 0.24$ & $1.31^{b} \pm 0.22$ & $1.67^{\mathrm{a}} \pm 0.33$ & $1.63^{\mathrm{a}} \pm 0.32$ & $1.60^{\mathrm{a}} \pm 0.32$ & $1.78^{\mathrm{a}} \pm 0.35$ & $1.63^{\mathrm{a}} \pm 0.34$ \\
\hline & Meat & $2.39^{\mathrm{b}} \pm 0.28$ & $3.55^{\mathrm{a}} \pm 0.30$ & $3.49^{\mathrm{a}} \pm 0.27$ & $3.62^{\mathrm{a}} \pm 0.25$ & $3.56^{\mathrm{a}} \pm 0.27$ & $3.50^{\mathrm{a}} \pm 0.31$ & $3.60^{\mathrm{a}} \pm 0.21$ \\
\hline & Oxidized & $0.38^{a} \pm 0.03$ & $0.48^{a} \pm 0.05$ & $0.39^{\mathrm{a}} \pm 0.04$ & $0.40^{\mathrm{a}} \pm 0.04$ & $0.47^{\mathrm{a}} \pm 0.04$ & $0.43^{\mathrm{a}} \pm 0.04$ & $0.43^{\mathrm{a}} \pm 0.04$ \\
\hline \multirow[t]{2}{*}{ Texture } & Softness & $5.51^{\mathrm{a}} \pm 0.22$ & $3.41^{b c} \pm 0.23$ & $3.53^{\mathrm{b}} \pm 0.24$ & $3.39^{\mathrm{bc}} \pm 0.23$ & $3.42^{\mathrm{bc}} \pm 0.22$ & $3.53^{\mathrm{b}} \pm 0.22$ & $3.29^{c} \pm 0.19$ \\
\hline & Succulent & $3.36^{a} \pm 0.27$ & $2.53^{b c} \pm 0.23$ & $2.49^{b c} \pm 0.26$ & $2.55^{\mathrm{b}} \pm 0.26$ & $2.53^{b c} \pm 0.23$ & $2.56^{a} \pm 0.25$ & $2.34^{c} \pm 0.21$ \\
\hline \multirow[t]{6}{*}{ Taste } & Salty & $1.45^{\mathrm{a}} \pm 0.19$ & $1.47^{\mathrm{a}} \pm 0.19$ & $1.39^{\mathrm{a}} \pm 0.18$ & $1.47^{\mathrm{a}} \pm 0.26$ & $1.40^{\mathrm{a}} \pm 0.18$ & $1.52^{\mathrm{a}} \pm 0.28$ & $1.37^{\mathrm{a}} \pm 0.24$ \\
\hline & Acid & $2.67^{\mathrm{a}} \pm 0.25$ & $2.38^{\mathrm{b}} \pm 0.28$ & $2.57^{\mathrm{ab}} \pm 0.27$ & $2.43^{\mathrm{b}} \pm 0.26$ & $2.57^{\mathrm{ab}} \pm 0.30$ & $2.54^{\mathrm{ab}} \pm 0.31$ & $2.54^{\mathrm{ab}} \pm 0.29$ \\
\hline & Rancidity & $1.42^{\mathrm{ab}} \pm 0.24$ & $1.51^{\mathrm{ab}} \pm 0.19$ & $1.57^{\mathrm{a}} \pm 0.21$ & $1.41^{\mathrm{ab}} \pm 0.24$ & $1.36^{\mathrm{b}} \pm 0.19$ & $1.44^{\mathrm{ab}} \pm 0.23$ & $1.54^{\mathrm{ab}} \pm 0.28$ \\
\hline & Smoked & $2.46^{\mathrm{a}} \pm 0.05$ & $0.35^{c} \pm 0.04$ & $0.63^{\mathrm{b}} \pm 0.09$ & $0.64^{\mathrm{b}} \pm 0.08$ & $0.62^{\mathrm{b}} \pm 0.09$ & $0.64^{\mathrm{b}} \pm 0.09$ & $0.60^{b} \pm 0.09$ \\
\hline & Spicy & $0.49^{\mathrm{a}} \pm 0.04$ & $0.50^{\mathrm{a}} \pm 0.05$ & $0.53^{\mathrm{a}} \pm 0.06$ & $0.56^{\mathrm{a}} \pm 0.11$ & $0.51^{\mathrm{a}} \pm 0.06$ & $0.48^{\mathrm{a}} \pm 0.04$ & $0.44^{\mathrm{a}} \pm 0.04$ \\
\hline & Spiced & $0.46^{\mathrm{ab}} \pm 0.04$ & $0.44^{\mathrm{ab}} \pm 0.05$ & $0.34^{\mathrm{b}} \pm 0.04$ & $0.40^{\mathrm{ab}} \pm 0.05$ & $0.42^{\mathrm{ab}} \pm 0.05$ & $0.52^{\mathrm{ab}} \pm 0.04$ & $0.55^{\mathrm{a}} \pm 0.05$ \\
\hline
\end{tabular}

F1 - traditional cultures without fat and curing salts reduction (nitrite and nitrate $0.015 \% 0.005 \%$ ); F2 - traditional cultures without curing salts reduction; F3 - traditional cultures with curing salts reduction (nitrite and nitrate $0.007 \% 0.003 \%$ ); F4 and F5 - probiotic culture (E. faecium CRL183) without and with curing salts reduction, respectively; F6 and F7 - probiotic culture (L. acidophilus CRL1014) without and with curing salts reduction, respectively. Means with the same letter on the same line do not differ by Tukey test ( $<<0.05$ ).

F5 and F6 were located in the positive region of the PC2, next to vectors PI and MA.

The results of the analysis of variance and the Tukey test (Table 4) showed no significant difference between the formulations for attributes oxidized, salty and smoked $(p<0.05)$. Formulation F1 (control formulation) showed the highest intensity for attributes regularity of the border, amount of fat, brightness, softness and rancidity and the lowest mean values for color, uniformity fat and acid, therefore differing from all other formulations $(p<0.05)$. Formulation $\mathrm{F} 2$ showed the lowest mean values for aroma and spicy flavor. On the other hand, the salami fermented with E. faecium CRL 183 and curing salt reduction (F6) was the most succulent, without significantly differing from the control formulation $(\mathrm{p}<0.05)$. Finally, formulation F3 (traditional cultures, fat and curing salt reduction) exhibited the highest mean value for acid taste, only differing from formulation F5, and the lowest mean value for spicy flavor, only differing from the probiotic salami, F7 ( $\mathrm{p}<0.05)$. 


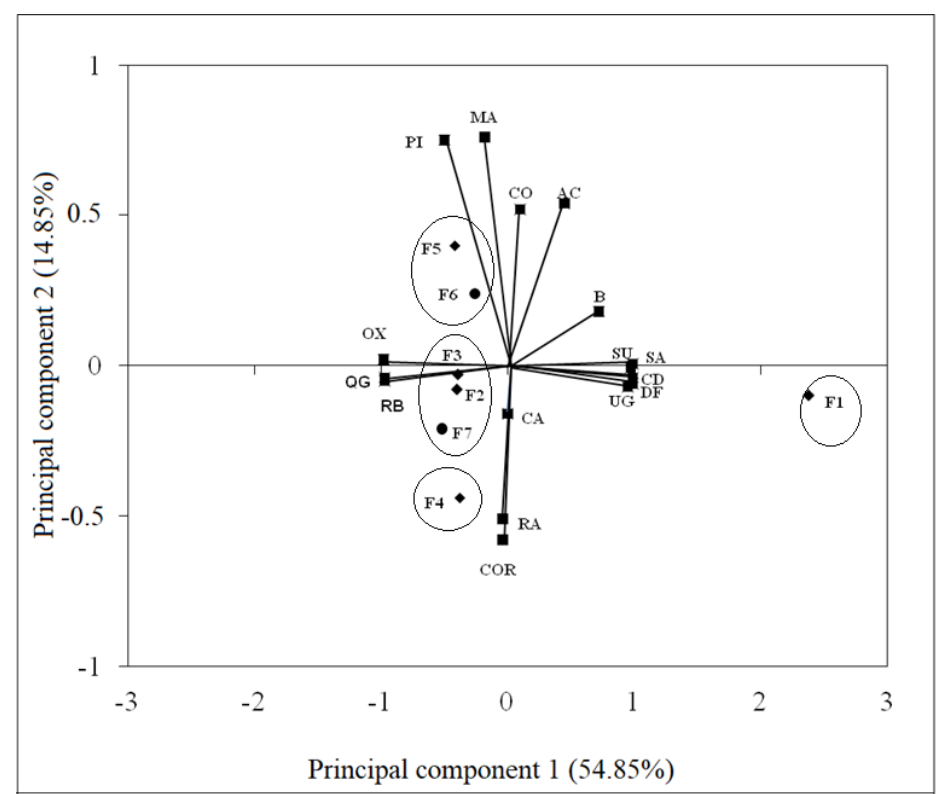

Figure 2. PCA chart of different formulations. APPEARANCE: Color (COR), amount of fat (QG), uniformity fat (UG), regularity of the border (RB), brightness (B); AROMA: spiced (CO), meat (CA), oxidized (OX); TEXTURE: softness (MA), succulent (SU); TASTE: salty (SA), spiced (CD), acid (AC), rancidity (RA), smoked (DF), spicy (PI). F1 - traditional cultures without fat and curing salts reduction (nitrite and nitrate $0.015 \% 0.005 \%) ; \mathrm{F} 2$ - traditional cultures without curing salts reduction; F3 - traditional cultures with curing salts reduction (nitrite and nitrate $0.007 \%$ 0.003\%); F4 and F5 - probiotic culture (E. faecium CRL183) without and with curing salts reduction, respectively; F6 and F7 - probiotic culture (L. acidophilus CRL1014) without and with curing salts reduction, respectively.

The results obtained in the QDA were as expected since the fat content reduction is directly affects the product's texture (softness and succulence), which can be confirmed by the instrumental data of texture.

Gómez \& Lorenzo (2013) evaluated the effect of fat reduction on a typical Spanish product, the chorizo. The results showed significant differences in cohesiveness, odor intensity, pepper odor and hardness between the samples produced with and without reduction in pork fat.

The results of this study indicate that the reduction in nitrite content and the replacement of traditional cultures for probiotic ones did not alter the aroma and taste of the samples. Despite the presence of nitrite be related to the characteristic red color of cured meats (Fox \& Ackerman, 1968; Sebranek \& Fox, 1985) there was no change in the perception of this attribute in this study due to the reduction of curing salts. Mora-Gallego et al. (2013) also evaluated the effect of reducing and replacing animal fat in sensory and instrumental properties of fermented salamis. Formulations with a minimum reduction of $70 \%$ animal fat (5\% addition of animal fat, sunflower oil or diglycerides) demonstrated similar behavior to the control formulation (no fat reduction). Nevertheless, the addition of sunflower oil still improved the aroma, taste and texture of the products.

\subsection{Acceptance testing}

Table 5 shows the values of appearance, color, aroma, texture, flavor and overall impression obtained in the acceptance test of the 7 formulations in 30 (product ready for consumption), 60, 90 and 120 days (of storage time).
The different formulations showed good acceptance for all attributes, as well as fat and curing salt reduction, and replacing traditional starter cultures for probiotic ones did not influence the hedonic impression of consumers by the end of the ripening period $(\mathrm{T} 30)(\mathrm{p}<0.05)$.

During the storage period (T60 to T120), the evaluated attributes remained highly graded, with mean values close to 7.0 for the different formulations. At the end of the 120 days of storage, the potentially probiotic samples exhibited lower acceptance mean values for appearance (F5=Enterococcus faecium CRL183) and texture (F6=Lactobacillus acidophilus CRL1014), without interfering with the overall impression of the samples $(\mathrm{p}<0.05)$.

The results of the purchase intention survey (Figure 3) confirmed the results of the acceptance test and, at all analyzed times, over $60 \%$ of the consumers would certainly or probably buy the products, with the exception of F3 and F6 formulations in T60 (48\% and 47\%, respectively, would certainly or probably purchase the product). The partial replacement of animal fats for olive oil was noticed by assessors in the descriptive analysis. However, the identified changes did not affect the overall acceptance of the products.

Other authors evaluated the effect of including vegetable oils to replace animal fat in fermented meat products and the results were similar to those found in this study. Backes et al. (2013) evaluated the effect of the partial replacement of pork fat for emulsion containing canola oil in an Italian salami type. In their study, three formulations were evaluated: a control formulation (100\% pork fat without replacing fat); 
Table 5. Means ( \pm standard deviations) of acceptance values for each attribute evaluated in different formulations.

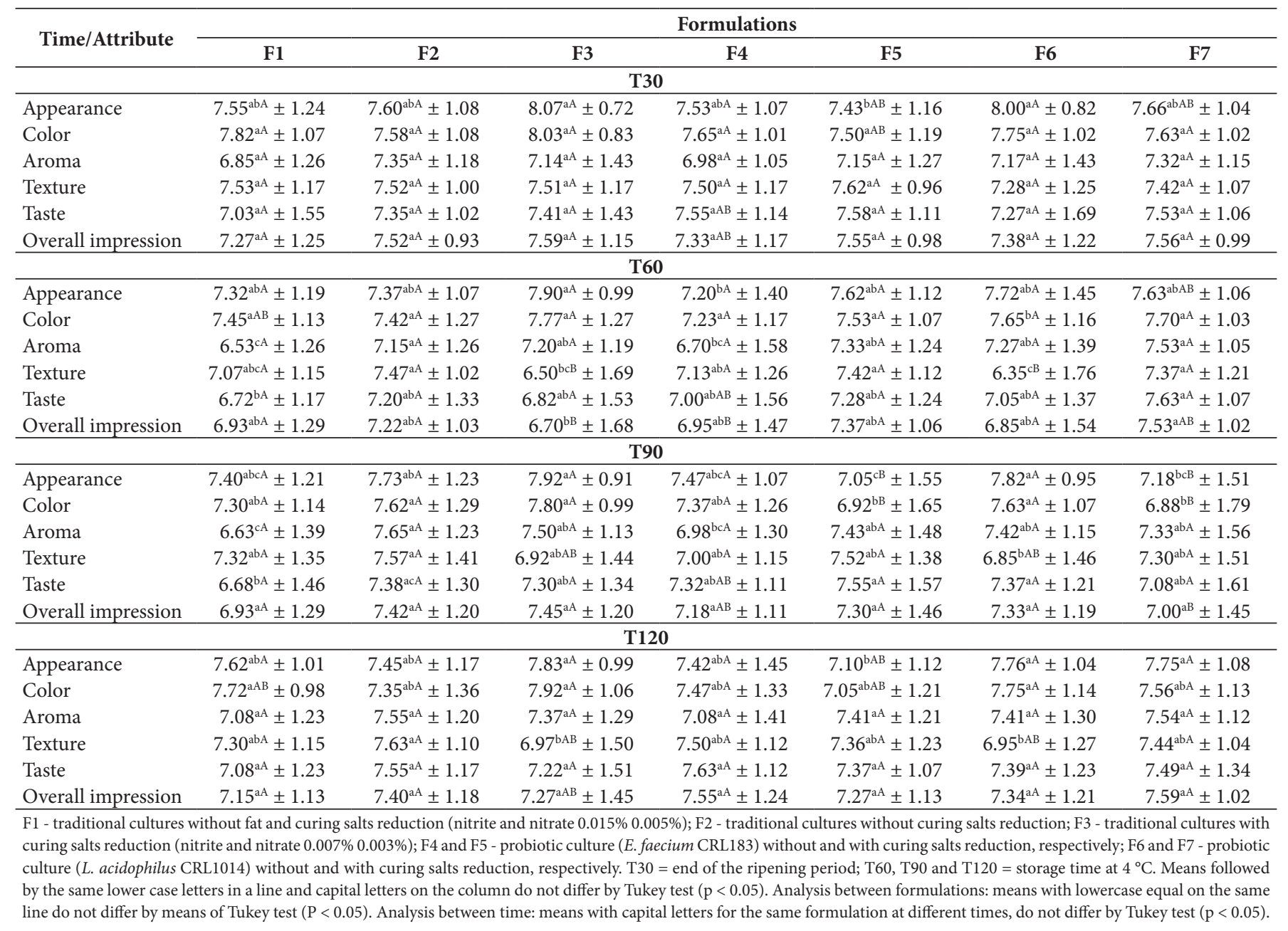

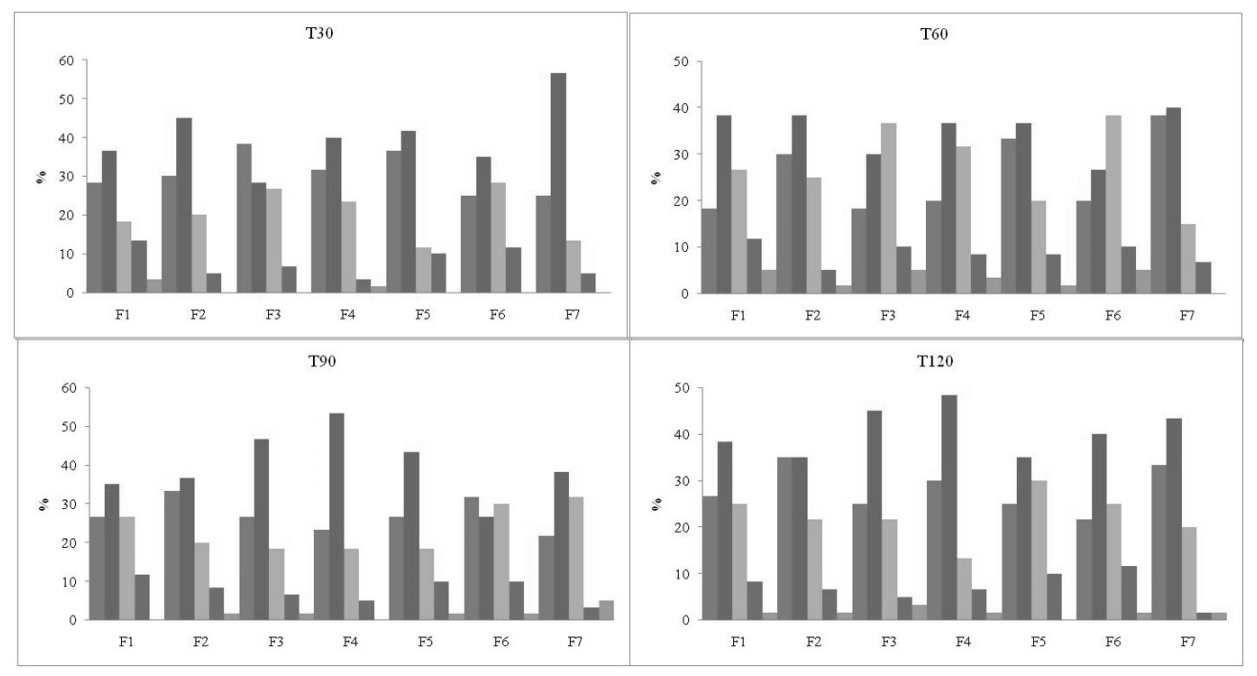

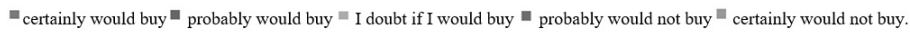

Figure 3. Frequency distribution of the notes corresponding to the scale used to assess the purchase intention of the products ready for consumption (T30) and during the storage period (T60, T90 and T120). F1 - traditional cultures without fat and curing salts reduction (nitrite and nitrate $0.015 \% 0.005 \%) ; \mathrm{F} 2$ - traditional cultures without curing salts reduction; F3 - traditional cultures with curing salts reduction (nitrite and nitrate $0.007 \% 0.003 \%$ ); F4 and F5 - probiotic culture (E. faecium CRL183) without and with curing salts reduction, respectively; F6 and F7 - probiotic culture (L. acidophilus CRL1014) without and with curing salts reduction, respectively. 
T1 (15\% of pork fat replacement for emulsion containing canola oil) and T2 (30\% of pork fat replacement for emulsion with oil canola). The acceptance of the samples was evaluated using a seven-point hedonic scale, ranging from extremely disliked (1) to extremely liked (7). The acceptance values obtained for all formulations and attributes were next to five (5), indicating that the replacement of animal fat for vegetable oil did not affect the acceptance of the product.

Bloukas \& Paneras (1993) studied the effect of replacing animal fat for olive oil in dry fermented salamis. Five formulations were produced: A) A control formulation (24\% beef, $43 \%$ pork and $22 \%$ pork fat, B) and C) replacing $10 \%$ and $20 \%$ animal fat for olive oil, respectively, and D) and E) replacing $10 \%$ and $20 \%$ animal fat for pre-emulsified olive oil with soy protein isolate, respectively. The sensory characteristic evaluation of the different formulations were carried out using a seven-point scale ( 7 = excellent; 6 = very good; 5 = good; 4 = acceptable; 3 = fair; 2 = slightly unacceptable; 1 = unacceptable). The salamis produced with pre-emulsified olive oil showed similar sensory characteristics to the control formulation with sensory mean values exceeding five for aroma and taste, wherein the added oil content did not influence the results. On the other hand, the replacement of animal fat for olive oil negatively alters the sensory characteristics of the fermented products as well as the product developed by Menegas et al. (2013) using corn oil as a substitute.

\section{Conclusion}

The results indicate that it was possible to obtain a potentially probiotic fermented salami, and that, the replacing of the animal fat, the reduction in curing salts content and replacement of traditional cultures for probiotic ones does not compromise the chemical composition or the acceptance of salamis, besides the QDA and texture profile differences between formulations with reduced fat and control. All formulations showed a positive purchase intention, indicating that the functional sausages exhibit potential to be inserted in the market.

\section{Acknowledgements}

This research was supported by FAPESP (Fundação de Amparo à Pesquisa do Estado de São Paulo, Brazil) that provided the financial support.

\section{References}

Amerine, M. A., Pangborn, R. M., \& Roessler, E. B. (1965). Principles of sensory evaluation of food. New York: Academic Press.

Ammor, M. S., \& Mayo, B. (2007). Selection criteria for lactic acid bacteria to be used as functional starter cultures in dry sausage production: an update. Meat Science, 76(1), 138-146. http://dx.doi. org/10.1016/j.meatsci.2006.10.022. PMid:22064200.

Andrés, S. C., García, M. E., Zaritzky, N. E., \& Califano, A. N. (2006). Storage stability of low-fat chicken sausages. Journal of Food Engineering, 72(4), 311-319. http://dx.doi.org/10.1016/j.jfoodeng.2004.08.043.

Association of Official Analytical Chemists - AOAC. (2005). Official methods of analysis of the Association of Official Analytical Chemists (16th ed.). Arlington: AOAC International.
Backes, A. M., Terra, N. N., Milani, L. I. G., Rezer, A. P. S., Lüdtke, F. L., Cavalheiro, C. P., \& Fries, L. L. M. (2013). Características físicoquímicas e aceitação sensorial de salame tipo Italiano com adição de óleo de canola. Semina: Ciências Agrárias, 34(6), 3709-3720. http:// dx.doi.org/10.5433/1679-0359.2013v34n6Supl2p3709.

Bedani, R. (2008). Influência do consumo de "iogurte" de soja fermentado com Enterococcus faecium CRL 183 na microbiota intestinal de animais e humanos (Tese de doutorado). Universidade Estadual Paulista, Araraquara.

Bloukas, J. G., \& Paneras, E. D. (1993). Substituting olive oil pork backfat affects quality of low lat frankfurters. Journal of Food Science, 58(4), 705-709. http://dx.doi.org/10.1111/j.1365-2621.1993.tb09339.x.

Bolumar, T., Toepfl, S., \& Heinz Pol, V. (2015). Fat reduction and replacement in dry-cured fermented sausage by using high pressure processing meat as fat replacer and olive oil. Journal of Food and Nutrition Sciences, 65(3):175-182.

Bourne, M. C. (1978). Texture profile analysis. Food Technology, 32:62-66, 72.

Brasil, Ministério da Agricultura, Pecuária e do Abastecimento. (2000, August 3). Instrução Normativa $n^{\circ} .22$ de 31 de julho de 2000. Regulamentos Técnicos de Identidade de Qualidade de Salames. Diário Oficial [da] República Federativa do Brasil.

Cadena, R. S., \& Bolini, H. M. A. (2011). Time-intensity analysis and acceptance test for traditional and light vanilla ice cream. Food Research International, 44(3), 677-683. http://dx.doi.org/10.1016/j. foodres.2010.12.012.

Candogan, K., \& Kolsarici, N. (2003). The efects of carrageenan and pectin some quality characteristics of low-fat beef frankfurters. Meat Science, 64(2), 199-206. http://dx.doi.org/10.1016/S03091740(02)00181-X. PMid:22062867.

Cavallini, D. C. U., Suzuki, J. Y., Abdalla, D. S. P., Vendramini, R. C., Pauly-Silveira, N. D., Roselino, M. N., Pinto, R. A., \& Rossi, E. A. (2011). Influence of a probiotic soy product on fecal microbiota and its association with cardiovascular risk factors in an animal model. Lipids in Health and Disease, 10(1), 126. http://dx.doi. org/10.1186/1476-511X-10-126. PMid:21801422.

Cavallini, D. C. U., Jovenasso Manzoni, M., Bedani, R., Roselino, M., Celiberto, L., Vendramini, R., de Valdez, G., Saes Parra Abdalla, D., Pinto, R. A, Rosetto, D., Valentini, S. R., \& Rossi, E. A. (2016). Probiotic soy product supplemented with isoflavones improves the lipid profile of moderately hypercholesterolemic men: a randomized controlled trial. Nutrients, 8(12), 52. http://dx.doi.org/10.3390/ nu8010052.

Celiberto, L. S., Bedani, R., Rossi, E. A., \& Cavallini, D. C. U. (2015). Probiotics: the scientific evidence in the context of inflammatory bowel disease. Critical Reviews in Food Science and Nutrition, 57(9), 1759-1768. http://dx.doi.org/10.1080/10408398.2014.941457.

Damásio, M. H., \& Costell, E. (1991). Análisis sensorial descriptivo: generación de descriptores y selección de catadores. Revista de Agroquímica y Tecnología de Alimentos., 31, 165-178.

Del Nobile, M. A., Conte, A., Incoronato, A. L., Panza, O., Sevi, A., \& Marino, R. (2009). New strategies for reducing the pork back-fat content in typical Italian salami. Meat Science, 81(1), 263-269. http://dx.doi.org/10.1016/j.meatsci.2008.07.026. PMid:22063993.

Fox, J. B. Jr., \& Ackerman, S. A. (1968). Formation of nitric oxide myoglobin: mechanisms of the reaction with various reductants. Journal of Food Science, 33(4), 364-370. http://dx.doi.org/10.1111/j.1365-2621.1968. tb03631.x.

Fuchs, R. H. B., Borsato, D., Bona, E., \& Hauly, M. C. O. (2005). "Iogurte" de soja suplementado com oligofrutose e inulina. Food 
Science and Technology, 25(1), 175-181. http://dx.doi.org/10.1590/ S0101-20612005000100029.

Gómez, M., \& Lorenzo, J. M. (2013). Effect of fat level on physicochemical, volatile compounds and sensory characteristics of dry-ripened "chorizo" from Celta pig breed. Meat Science, 95(3), 658-666. http:// dx.doi.org/10.1016/j.meatsci.2013.06.005. PMid:23811106.

Gonzalez, N. J., Adhikari, K., \& Sancho-Madriz, M. F. (2011). Sensory characteristics of peach-flavored yogurt drinks containing prebiotics and synbiotics. Lebensmittel-Wissenschaft + Technologie, 44(1), 158163. http://dx.doi.org/10.1016/j.lwt.2010.06.008.

Kinouchi, F. L. (2006). "Iogurte" de soja como coadjuvante no tratamento de cancer de mama (Tese de doutorado). Universidade Estadual Paulista, Araraquara.

Koutsopoulos, D. A., Koutsimanis, G. E., \& Bloukas, J. G. (2008). Effect of carrageenan level and packaging during ripening on processing and quality characteristics of low-fat fermented sausages produced with olive oil. Meat Science, 79(1), 188-197. http://dx.doi.org/10.1016/j. meatsci.2007.08.016. PMid:22062612.

Kunrath, C. A., \& Savoldi, D. C. (2014). Propolis as antioxidant in meat products: aplication and evaluation in Italian Salami Type (Trabalho de Conclusão de Curso). Universidade Tecnológica Federal do Paraná, Francisco Beltrão - Paraná.

Liaros, N. G., Katsanidis, E., \& Bloukas, J. G. (2009). Effect of the ripening time under vacuum and packaging film permeability on processing and quality characteristics of low-fat fermented sausages. Meat Science, 83(4), 589-598. http://dx.doi.org/10.1016/j. meatsci.2009.07.006. PMid:20416653.

Macedo, R. E. F., Pflanzer, S. B. Jr., Terra, N. N., \& Freitas, R. J. S. (2008). Desenvolvimento de embutido fermentado por Lactobacillus probióticos: características de qualidade. Food Science and Technology (Campinas), 28(3), 509-519. http://dx.doi.org/10.1590/S010120612008000300002.

Macfie, H. J., Bratchell, N., Greenhoff, K., \& Vallis, L. (1989). Designs to balance the effect of order of presentation and first-order carryover effects in Hall tests. Journal of Sensory Studies, 4(2), 129-148. http://dx.doi.org/10.1111/j.1745-459X.1989.tb00463.x.

Meilgaard, M., Vance Civille, G., \& Thomas Carr, B. (1999). Sensory evaluation techniques. Boca Raton: CRC Press. http://dx.doi. org/10.1201/9781439832271.

Menegas, L. Z., Pimentel, T. C., Garcia, S., \& Prudencio, S. H. (2013). Dry-fermented chicken sausage produced with inulin and corn oil: Physicochemical, microbiological, and textural characteristics and acceptability during storage. Meat Science, 93(3), 501-506. http:// dx.doi.org/10.1016/j.meatsci.2012.11.003. PMid:23273457.

Mora-Gallego, H., Serra, X., Guardiã, M. D., Miklos, R., Lametsch, R., \& Arnau, J. (2013). Effect of the type of fat on the physicochemical, instrumental and sensory characteristics of reduced fat non-acid fermented sausages. Meat Science, 93(3), 668-674. http://dx.doi. org/10.1016/j.meatsci.2012.11.042. PMid:23273479.

Moskowitz, H. R. (1983). Product testing and sensory evaluation of foods: marketing and R\&D approaches. Westport, Conn., USA: Food \& Nutrition Press.

Muthukumarasamy, P., \& Holley, R. (2007). Survival of Escherichia coli O157:H7 in dry fermented sausages containing micro-encapsulated probiotic lactic acid bacteria. Food Microbiology, 24(1), 82-88. http:// dx.doi.org/10.1016/j.fm.2006.03.004. PMid:16943098.
Pidcock, K., Heard, G. M., \& Henriksson, A. (2002). Application of nontraditional meat starter cultures in production of Hungarian salami. International Journal of Food Microbiology, 76(1-2), 75-81. http://dx.doi.org/10.1016/S0168-1605(02)00002-8. PMid:12038580.

Rossi, E. A., Giori, G. S., Holgado, A. P. R., \& Valdez, G. F. (1994). In vitro effect of Enterococcus faecium and Lactobacillus acidophilus on cholesterol. Microbiologie-aliments-nutrition., 12, 267-270.

Rubio, R., Jofré, A., Aymerich, T., Guàrdia, M. D., \& Garriga, M. (2014a). Nutritionally enhanced fermented sausages as a vehicle for potential probiotic lactobacilli delivery. Meat Science, 96(2 Pt A), 937-942. http://dx.doi.org/10.1016/j.meatsci.2013.09.008. PMid:24211552.

Rubio, R., Martín, B., Aymerich, T., \& Garriga, M. (2014b). The potential probiotic Lactobacillus rhamnosus CTC1679 survives the passage through the gastrointestinal tract and its use as starter culture results in safe nutritionally enhanced fermented sausages. International Journal of Food Microbiology, 186, 55-60. http://dx.doi.org/10.1016/j. ijfoodmicro.2014.06.013. PMid:24998181.

Sebranek, J. G., \& Fox, J. B. (1985). A review of nitrite and chloride chemistry: interactions and implications for cured meats. Journal of the Science of Food and Agriculture, 36(11), 1169-1182. http:// dx.doi.org/10.1002/jsfa.2740361122.

Severini, C., De Pilli, T., \& Baiano, A. (2003). Partial substitution of pork backfat with extra-virgin olive oil in " salami " products : effects on chemical, physical and sensorial quality. Meat Science, 64(3), 323-331. http://dx.doi.org/10.1016/S0309-1740(02)00204-8. PMid:22063019.

Sidira, M., Kandylis, P., Kanellaki, M., \& Kourkoutas, Y. (2016). Effect of curing salts and probiotic cultures on the evolution of flavor compounds in dry-fermented sausages during ripening. Food Chemistry, 201, 334-338. http://dx.doi.org/10.1016/j.foodchem.2016.01.084. PMid:26868585.

Sivieri, K., Spinardi-Barbisan, A. L. T., Barbisan, L. F., Bedani, R., Pauly, N. D., Carlos, I. Z., Benzatti, F., Vendramini, R. C., \& Rossi, E. A. (2008). Probiotic Enterococcus faecium CRL 183 inhibit chemically induced colon cancer in male rats. European Food Research and Technology, 228(2), 231-237. http://dx.doi.org/10.1007/s00217008-0927-6.

Stone, H., \& Sidel, J. L. (1993). Sensory evaluation pratices ( $2^{\text {nd }}$ ed.). London: Academic.

Stone, H., Bleibaum, R. N., \& Thomas, H. A. (2012). Sensory evaluation practices. Elsevier: New York.

Terra, N. N. (1998). Apontamentos de tecnologia de carnes. São Leopoldo: UNISINOS.

Työppönen, S., Petäjä, E., \& Mattila-Sandholm, T. (2003). Bioprotectives and probiotics for dry sausages. International Journal of Food Microbiology, 83(3), 233-244. http://dx.doi.org/10.1016/S01681605(02)00379-3. PMid:12745229.

Volpini-Rapina, L. F., Sokei, F. R., \& Conti-Silva, A. C. (2012). Sensory profile and preference mapping of orange cakes with addition of prebiotics inulin and oligofructose. Lebensmittel-Wissenschaft + Technologie, 48(1), 37-42. http://dx.doi.org/10.1016/j.lwt.2012.03.008.

Wakeling, I. N., \& MacFie, H. J. H. (1995). Designing consumer trials balanced forfirst and higher orders of carry-over effect when only a subset of k samples from $t$ may be tested. Food Quality and Preference, 6(4), 299-308. http://dx.doi.org/10.1016/0950-3293(95)00032-1. 